\section{Finniston's pale shadow}

The British Engineering Council now exists.

\section{Its first task is to define for itself a role.}

Engineering education promises to be in the 1980 s a lightningrod for public solicitude to take the place occupied in the $1950 \mathrm{~s}$ by the cause of motherhood. In the United States last week, Dr George Keyworth was wringing his hands before Congress in anxiety about the difficulties of recruiting and then keeping members of university engineering faculties - but was confident that the market would somehow find a way. In Britain, engineering education has been a public issue for at least four years, since Sir Monty Finniston's committee was set up. Broadly speaking, there have been three distinct complaints. First, there is not enough engineering education. Second, what there is is either inappropriate or not good enough or both. And third, in universities as in the world outside, engineering has a lower status than science. Finniston's report (now nearly two years old) embraced all these views and more, and urged that there should be an Engineering Council equipped with powers over engineering curricula in all kinds of teaching institutions and with the funds with which to implement reforms. Implicitly, Finniston asked that his council should supersede the existing engineering institutions, some of them monuments to the Industrial Revolution.

The contrast between the United States and Britain is instructive. In both countries, it is acknowledged that engineering skill is one of the mainsprings of industrial innovation, productivity and prosperity. There, however, the similarity ends. Dr Keyworth last week was merely echoing the longstanding complaint that American industry is so fully seized of the economic importance of engineering skill that universities cannot easily compete for teachers - and graduates flock off to lucrative jobs in industry undiverted by the prestige of the academic life. In Britain, much the same may be happening in fields of engineering linked with computer engineering, but for the most part those carrying a torch for British engineering are still mouthing hackneyed slogans - that engineering (and engineers) should be accorded more "status" by everybody in sight.

This is the spirit in which the Committee of Engineering Professors has in the past few months been urging that the Science and Engineering Research Council should be split into two, one part concerned with the support of engineering research in universities. For, the argument seems to be, how can engineers respect themselves without a research council to call their own? (The proposal, mercifully, seems to have been headed off by the willingness of what used to be the Science Research Council to mention engineering in its title.) Similarly, there is excited talk, from people such as Lord Caldecote, the president of the Engineering Fellowship (another pressure group), that the new council may help to give the engineering professions public esteem. What these complainants consistently overlook is that the exercises in public relations on which they are embarked are merely palliatives, and that British engineering would be better off if its esteem were reflected in the eagerness of British industry to snap up young engineers - and to pay them decent salaries.

How is that to be accomplished? And will the new council help? Much will depend on its willingness to come to grips with the educational questions which Finniston grasped too firmly - like a man picking up a stinging nettle. In spite of the inquiries of the past four years, nobody is much wiser about the balance that should be struck between the various ingredients in various kinds of engineering courses. Instead, at the university level, the assumption is being established that there should be two kinds of courses, one lasting three years and one for four.

Unfortunately, very little thought has been given to the academic content of these courses, and the suspicion remains that university engineering courses, like those in other educational institutions, are too narrow because the separate engineering institutions too jealously insist that courses should concentrate on the topics judged to be relevant to their fields of interest.
Mechanical engineers worry about the design of gear wheels, civil engineers about the design of bridges, electrical engineers about the design of circuits and so on. The influence of the engineering institutions stems from their willingness to grant exemption from some of the requirements for professional qualification to students who have followed approved courses. This right will remain under the new arrangements. But who is to say that these are the lines on which engineers should be taught? Might not a preparation in something called engineering science be a better preparation for work in a profession that must turn its hand to almost everything? And how is the engineering profession to come to terms with the disconcerting truth that many whose academic training is quite different from that now required of engineers still function in industry as engineers? It would be splendid if the new council chose, as its constitution allows, to license the occasional physicist or chemist to practise as an engineer. Better still, it should take a fresh look at what academic preparation is needed by those who may in future keep British industry alive. But it should firmly acknowledge that a demand for more prestige for engineers is tantamount to a demand that water should run uphill.

\section{Who pays what piper?}

\section{British universities and football clubs are} in trouble. Can they make common cause?

Economic crisis is at least even-handed. Last week, British newspapers were full of gloomy prophecies of how no fewer than a dozen among three-score British institutions are threatened with bankruptcy in the months ahead. The causes are easily described. Running costs have risen. The cost of employing staffs has become doubly onerous - the annual salary bill is high, but the longer-term implications of people's contracts with their institutions are a shadow over the future. But income is falling. Traditional customers can no longer afford to take advantage of the services the institutions exist to provide. Inevitably, where the threatened institutions command particular loyalty from the cities in which they are based, especially when they are the only one of their kind, bands of loyal supporters have formed to conjure a phoenix from the impending ashes. Elsewhere, newspaper columnists comfortably bemoan the passing of a revered tradition and a past source of public pleasure and enlightenment. The institutions are the professional (commercial) football clubs that play with a round ball, otherwise known as soccer or "association football' clubs.

British academics reading this torrent of gush (which may be made meaningless if only the clubs can negotiate a better television contract next season) may be forgiven for not recognizing that much of the purple prose could apply to the institutions for which they work. The proportions at risk are about the same. The inexorable increase of expenditure has similar causes. And income is falling because the government, effectively the only customer, cannot afford to pay for the services on offer. But may not academics, most of whose institutions will be making critical decisions about their future this week and next, learn from what the football clubs are planning?

Many football clubs plan to make better use of their fixed plant; universities might similarly offer courses out of business hours or in vacations. Other clubs plan to increase their ancillary income; selling franchises to put university coats of arms on tee-shirts would hardly be lucrative, but what of the benefits from academic enterprises with which British univesities have so far only flirted? Some clubs plan to sell off players, presumably the most saleable and thus probably the best; but universities are thinking of offering early retirement only to the least employable. No football club lacks a local constituency, a group of people to which is has given pleasure in the past and which is now prepared to fight that it should have a future; too many universities, unfortunately, are unable to make a comparable claim on their localities. In a macabre way, it will be interesting to see which threatened group does best in the months ahead. 